\title{
Unilateral giant renal angiomyolipoma and pulmonary lymphangioleiomyomatosis
}

\author{
Fernando Peixoto Ferraz de Campos $^{a}$, Cristiane Rúbia Ferreirab ${ }^{b}$ Angélica Braz Simões ${ }^{b}$, \\ Paulo Sergio Martins de Alcântara ${ }^{c}$, Brenda Margatho Martines ${ }^{d}$, Adriano Ferreira da Silva ${ }^{d}$, \\ Deborah Azzi-Nogueira ${ }^{e}$, Luiz Roberto Giorgetti de Britto ${ }^{f}$, Luiz Gustavo Dufner-Almeidae, \\ Luciana Amaral Haddad ${ }^{\mathrm{e}}$
}

Campos FPF, Ferreira CR, Simões AB, et al. Unilateral giant renal angiomyolipoma and pulmonary lymphangioleiomyomatosis. Autopsy Case Rep [Internet]. 2013; 3(4): 53-62. http://dx.doi.org/10.4322/acr.2013.040

\section{ABSTRACT}

Angiomyolipomas (AMLs) are mesenchymal neoplasms, named so because of the complex tissue composition represented by variable proportions of mature adipose tissue, smooth muscle cells, and dysmorphic blood vessels. Although AMLs may rise in different sites of the body, they are mostly observed in the kidney and liver. In the case of renal AMLs, they are described in two types: isolated AMLs and AMLs associated with tuberous sclerosis (TS). While most cases of AMLs are found incidentally during imaging examinations and are asymptomatic, others may reach huge proportions causing symptoms. Pulmonary lymphangioleiomyomatosis (LAM) is a rare benign disease characterized by cystic changes in the pulmonary parenchyma and smooth muscle proliferation, leading to a mixed picture of interstitial and obstructive disease. AML and LAM constitute major features of tuberous sclerosis complex (TSC), a multisystem autosomal dominant tumor-suppressor gene complex diagnosis. The authors report the case of a young female patient who presented a huge abdominal tumor, which at computed tomography (CT) show a fat predominance. The tumor displaced the right kidney and remaining abdominal viscera to the left. Chest CT also disclosed pulmonary lesions compatible with lymphangioleiomyomatosis. Because of sudden abdominal pain accompanied by a fall in the hemoglobin level, the patient underwent an urgent laparotomy. The excised tumor was shown to be a giant renal AML with signs of bleeding in its interior. The authors call attention to the diagnosis of $\mathrm{AML}$ and the huge proportions that the tumor can reach, as well as for ruling out the TSC diagnosis, once it may impose genetic counseling implications..

Keywords: Angiomyolipoma; Kidney Diseases; Lymphangioleiomyomatosis; Hemorrhage; Nephrectomy; Tuberous Sclerosis.

\footnotetext{
a Department of Internal Medicine - Hospital Universitário - Universidade de São Paulo, São Paulo/SP - Brazil.

${ }^{\text {b }}$ Anatomic Pathology Service - Hospital Universitário - Universidade de São Paulo, São Paulo/SP - Brazil.

c Department of Surgery - Hospital Universitário - Universidade de São Paulo, São Paulo/SP - Brazil.

d Diagnostic Imaging Service - Hospital Universitário - Universidade de São Paulo, São Paulo/SP - Brazil.

e Department of Genetics and Evolutionary Biology - Instituto de Biociências - Universidade de São Paulo, São Paulo/SP - Brazil.

${ }^{f}$ Department of Physiology and Biophysics - Instituto de Ciências Biomédicas - Universidade de São Paulo, São Paulo/ SP - Brazil.
}

Copyright $\odot 2013$ Autopsy and Case Reports - This is an Open Access article distributed of terms of the Creative Commons Attribution NonCommercial License (http://creativecommons.org/licenses/by/3.0/) which permits unrestricted non-commercial use, distribution, and reproduction in any medium provided article is properly cited. 


\section{CASE REPORT}

A 26-year-old Caucasian female patient sought medical care, complaining of a 2-month right flank pain. Initially, this symptom had a 30 -minute duration and was usually triggered by physical exertion or by trunk flexion. The pain improved with rest. Gradually, the pain became more frequent and more intense, accompanied by stiffness of the abdominal wall and increased abdominal volume reaching proportions that resembled the abdomen of an advanced pregnancy. She reported weight loss of $3 \mathrm{~kg}$ in this period, postprandial bloating, and progressive exertional dyspnea. Fever was absent. Her past medical history included two pregnancies, one cesarean section 6 years before, and one vaginal delivery, 4 years ago. She was a smoker and her alcoholic beverage consumption was mild. On physical examination the patient was in good general condition, weight was $57 \mathrm{~kg}$, height was $1.59 \mathrm{~m}(\mathrm{BMI}=22.5)$, blood pressure was 120/80 $\mathrm{mmHg}$; pulse rate was 72 beats per minute, and she was afebrile. Examination of the skin, nails, and gums was normal. Upon inspection, the abdomen was asymmetric, right bulged where a hardened mass was palpable and painful, displacing the liver forward and to the left. The remainder of the physical examination was normal.

Initial laboratory tests are shown in Table 1. Urinalysis was normal. Serum determination of carcinoembrionic antigen (CEA) was < $0.5 \mathrm{ng} /$ $\mathrm{mL}$ (reference value [RV] until $2.5 \mathrm{ng} / \mathrm{mL}$ ), cancer antigen-125 (CA-125) $17 \mathrm{U} / \mathrm{mL}$ (RV: until $35 \mathrm{U} / \mathrm{mL}$ ); carcinoma antigen 15-3 (CA 15-3) $5.5 \mathrm{U} / \mathrm{mL}$ (RV: until 38.5 U/mL); carbohydrate antigen 19-9 (CA 199) 3.6 (RV: until $37 \mathrm{U} / \mathrm{mL}$ ).

The abdominal plain x-ray showed a homogeneous opacification occupying almost the entire right hemi abdomen displacing the bowel loops to the left (Figure 1).

The abdominal sonographic examination showed a poorly defined mass blurring the intra-

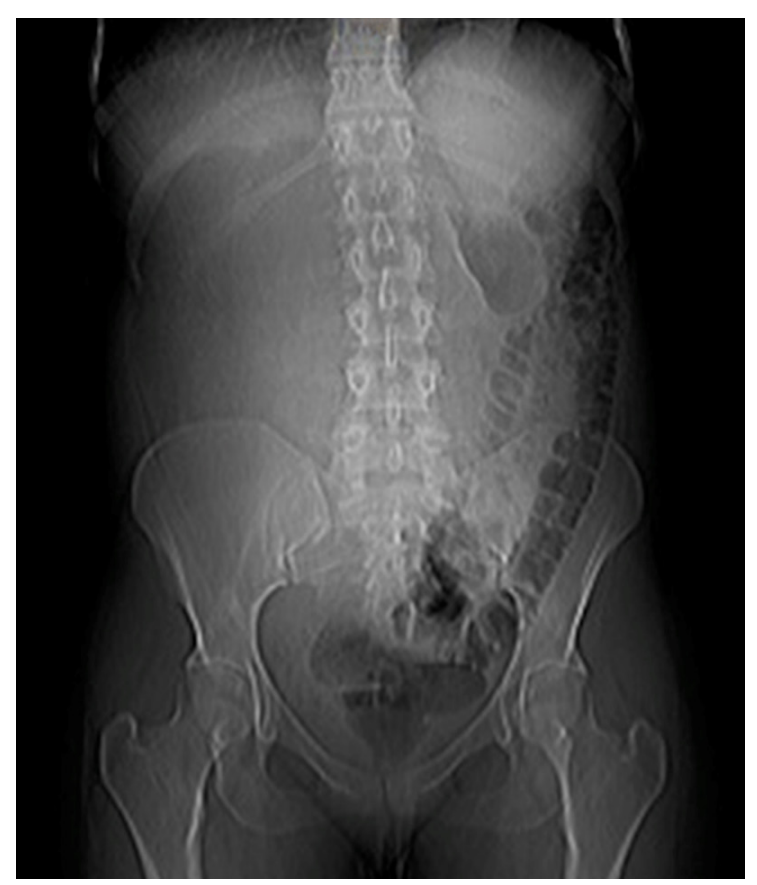

Figure 1 - Abdominal plain radiography showing the displacement of the bowel loops to the left and a homogeneous opacity filling the right hemiabdomen.

Table 1 - Initial laboratory workup

\begin{tabular}{cccccc}
\hline Exam & Result & RV & Exam & Result & RV \\
\hline Hemoglobin & 14.0 & $12.3-15.3 \mathrm{~g} / \mathrm{dL}$ & Glucose & 83 & $70-99 \mathrm{mg} / \mathrm{dL}$ \\
Hematocrit & 42.1 & $36.0-45.0 \%$ & Creatinine & 0.72 & $0.4-1.3 \mathrm{mg} / \mathrm{dL}$ \\
Leukocytes & 6.19 & $4.4-11.3 \times 10^{3} / \mathrm{mm}^{3}$ & Urea & 25 & $10-50 \mathrm{mg} / \mathrm{dL}$ \\
Segmented & 61 & $46-75 \%$ & Sodium & 138 & $136-146 \mathrm{mEq} / \mathrm{L}$ \\
Eosinophil & 4 & $1-4 \%$ & Potassium & 4.7 & $3.5-5.0 \mathrm{mEq} / \mathrm{L}$ \\
Basophil & 2 & $0-2.5 \%$ & CRP & $<5 \mathrm{mg} / \mathrm{L}$ & $<5.0 \mathrm{mg} / \mathrm{L}$ \\
Lymphocyte & 27 & $18-40 \%$ & INR & 1.10 & 1.0 \\
Monocyte & 6 & $2-9 \%$ & TP & 6.7 & $6.0-8.0 \mathrm{~g} / \mathrm{dL}$ \\
Platelet & 339 & $150-400 \times 10^{3} / \mathrm{mm}^{3}$ & Albumin & 4.2 & $3.0-5.0 \mathrm{~g} / \mathrm{dL}$ \\
\hline
\end{tabular}

$\mathrm{CRP}=\mathrm{C}$-reactive protein; INR = international normalized ratio; RV = reference value; $\mathrm{TP}=$ total protein. 
and retroperitoneal adipose tissue, preventing the identification of the pancreas and adjacent structures. This mass predominantly occupied the epigastric and mesogastric areas, shifting the intestinal bowels to the left and the right kidney anteriorly and to the left.

The abdominal computed tomography (CT) disclosed a huge retroperitoneal mass measuring $18.0 \times 17.0 \times 8.7 \mathrm{~cm}$, occupying almost the entire right side of the abdomen, exhibiting an intimate

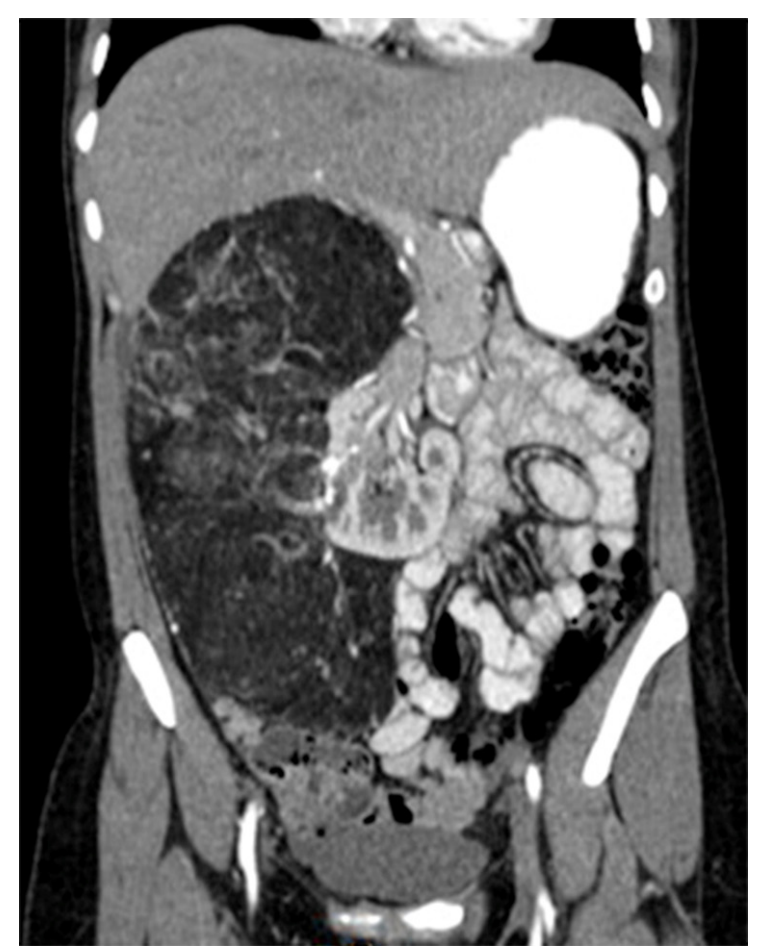

Figure 2 - Abdominal computed tomography (CT) - portal phase - coronal reformatted image showing a huge mass occupying half of the abdominal volume, crossing the midline, predominantly composed of adipose tissue interspersed with multiple vascular structures. The right kidney is displaced medially. Note the relationship of the mass with the renal parenchyma at its lower pole. relationship with the inferior pole of the right kidney. The right adrenal gland, pancreas, and intestinal bowels were shifted to the left. The heterogeneous mass was richly vascularized, presenting calibrous vessels adjacent to its inferior portion and exhibited a density predominantly of adipose tissue (Figures 2 and 3).

Evident lymph adenomegaly was not identified. The remaining organs in the abdomen were normal. Thoracic CT showed the presence of multiple cystic images throughout the lungs including the involvement of apices and costophrenic recesses (Figure 4) compatible with the diagnosis of lymphangioleiomyomatosis, without causing any change in the pulmonary function test. Brain CT and Doppler echocardiography were normal.

With these clinical, laboratory and imaging features, the hypothesis of angiomyolipoma (AML) was raised and surgery was indicated, due to the tumor size. While waiting for surgery, the patient presented an acute worsening of pain, hypotension, and pallor. At this time, a fall of $5.3 \mathrm{~g} / \mathrm{dL}$ in hemoglobin determination and $16.9 \%$ in hematocrit was observed.

Urgent laparotomy was undertaken and the surgical findings corresponded to a large tumoral mass originating from the anterior surface of the right kidney weighing $2,700 \mathrm{~g}$ enclosed into the retroperitoneum (Figure 5). The right renal and adrenal arteries and veins held the tumor blood supply. The right kidney and right adrenal were excised in conjunction with the tumoral mass. Postoperative recovery was uneventful, and the patient was discharged after 9 days.

Microscopic examination showed a tumor composed of three tissue components: mature

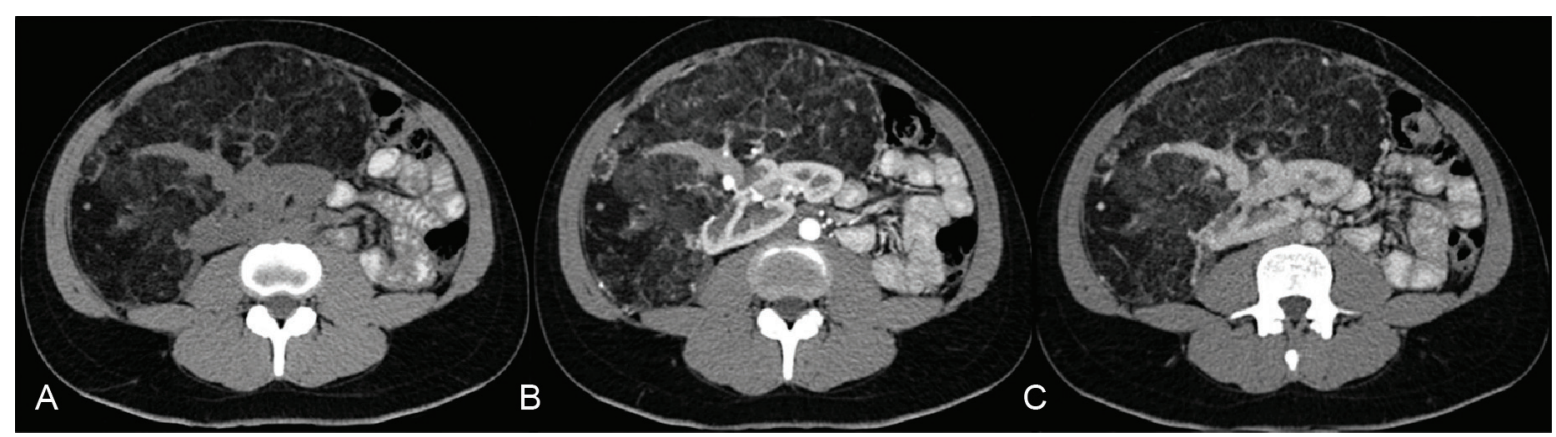

Figure 3-Abdominal axial CT. A - (Image without intravenous contrast injection.) A huge mass occupying the right half of the abdomen, crossing the midline, and consisting predominantly of adipose tissue is observed; B - Arterial phase; C - Portal phase. Note that the tumoral mass is interspersed with multiple vascular structures and the relationship of mass to the renal parenchyma at its lower pole. 
adipose tissue, convoluted thick-walled blood vessels with frequent hyalinization of the media, and interlacing bundles of smooth muscle often with perivascular arrangement (Figure 6). The immunohistochemical panel was positive for muscle actin and markers associated with melanoma antigen HMB-45 and Melan-A in the muscular component of the neoplasm (Figure 7).

\section{GENETICS ANALYSIS}

The patient reported here had no definite clinical diagnosis of TSC, suggesting isolated AML and LAM. Somatic mutations in either TSC1 or TSC2 genes have been reported in isolated AMLs and LAM. ${ }^{1,2}$ Most mutations in isolated renal AMLs have been reported in the TSC2 gene, mapped
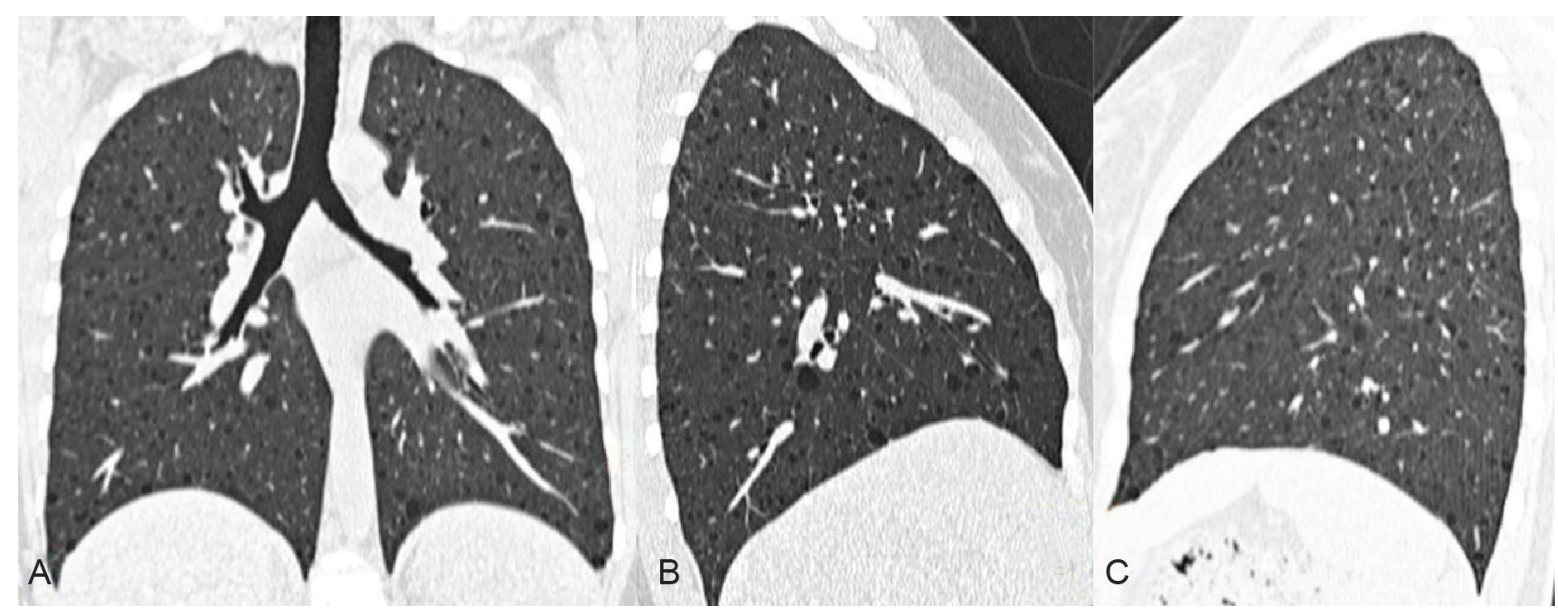

Figure 4 - Thoracic CT, lung window. A - Coronal; B - Right sagittal; C - Left sagittal. A, B, and C show several thin-walled pulmonary cysts that are relatively homogeneous in form and dimensions, diffusely distributed throughout the lung fields, including the apices and costophrenic sulci, compatible with lymphangioleiomyomatosis.
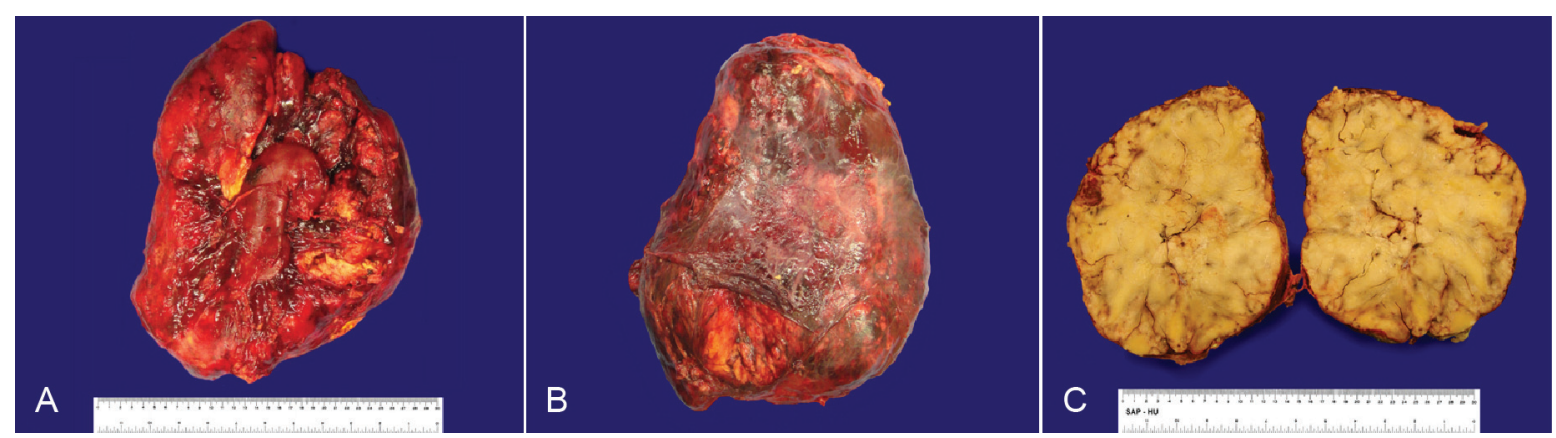

Figure $\mathbf{5}$ - Gross examination of the tumoral mass represented by a large yellowish and hemorrhagic mass measuring $24 \mathrm{~cm}$ in its longest axis; A - Right kidney depicted in the centrum of the tumor mass, losing definition of its contour at the inferior pole; $\mathbf{B}$ - Tumor covered by peritoneum; C- Note the abundance of the adipose tissue of the tumoral mass.

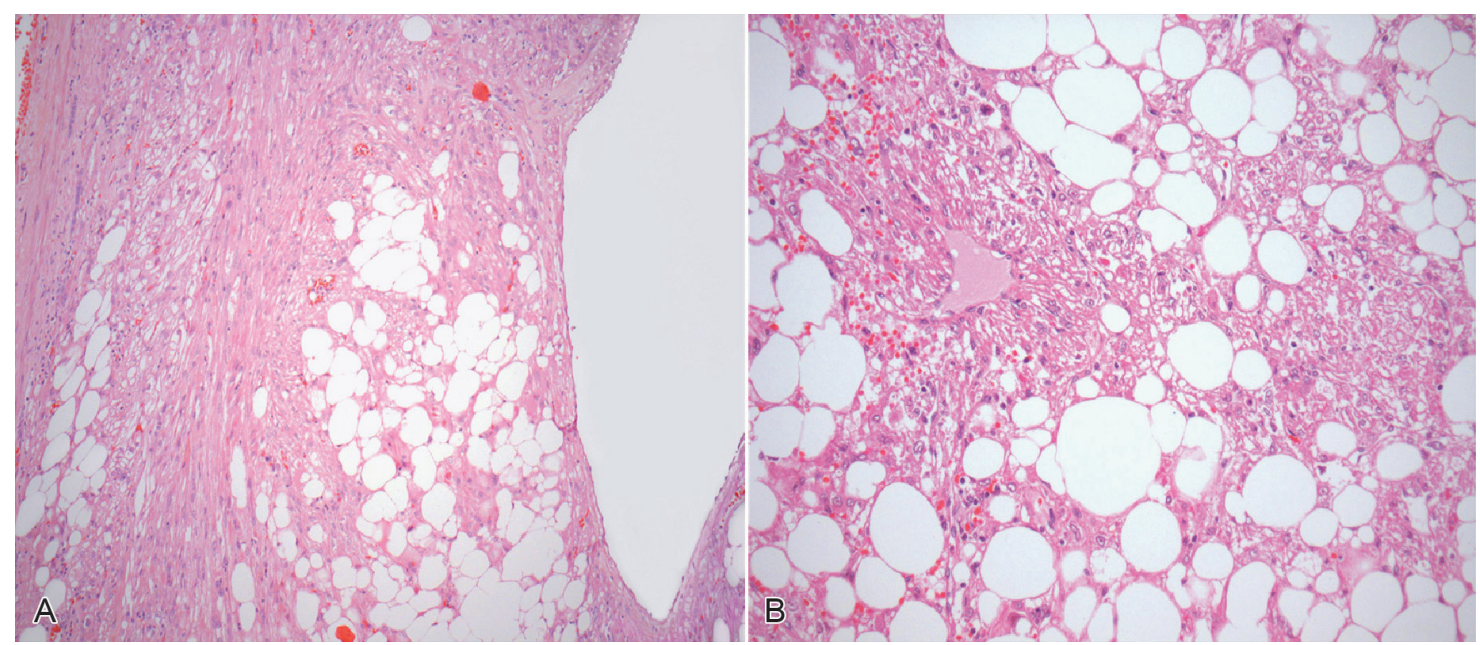

Figure 6 - Photomicrography of the tumoral mass. A and B - Renal angiomyolipoma ( $A M L)$ composed of adipose tissue, smooth muscle, and vessels (HE $10 \times 20)$. 


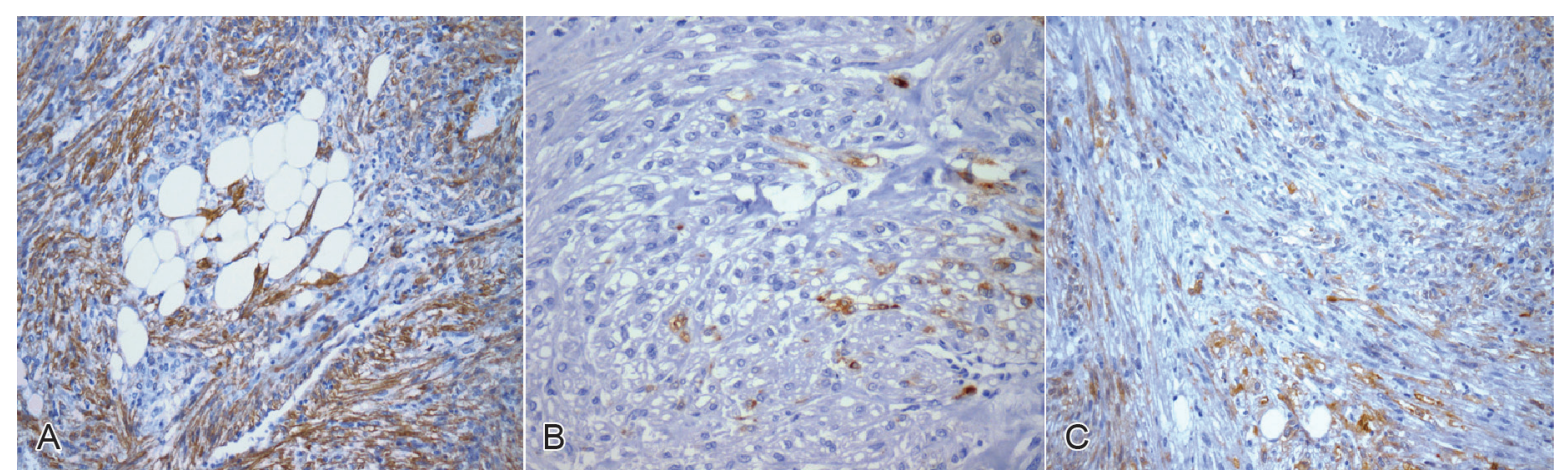

Figure 7 - Photomicrography of the tumoral mass. Renal AML showing positive immunoreactivity. A - Smooth muscle actin (AML); B - HMB-45; C - Melan A.
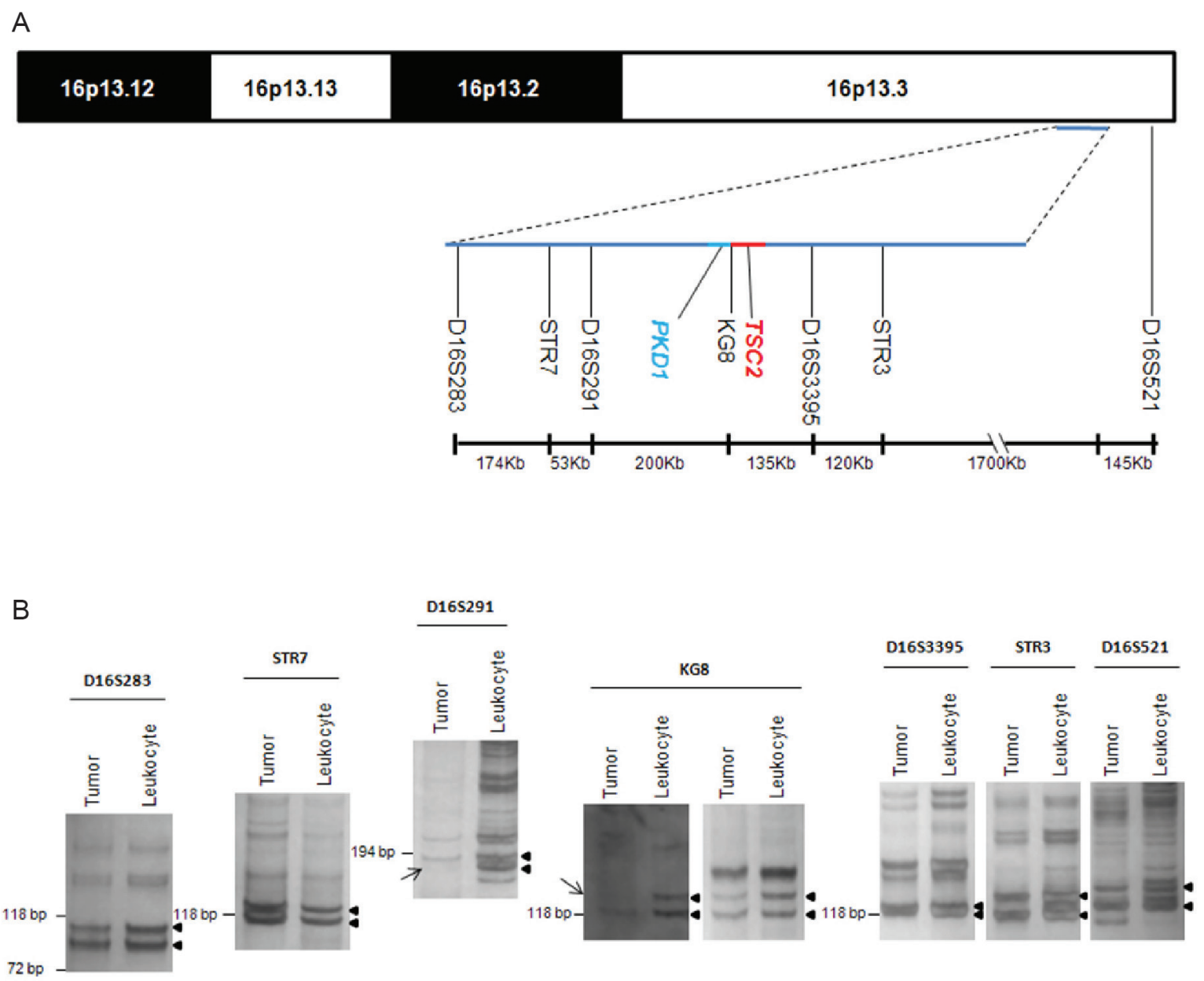

Figure 8 - A - Part of the short arm of human chromosome 16 is depicted, showing the localization of TSC2 gene, which partially overlaps with PKD1 gene. Molecular, polymorphic markers informative in this study are presented, as well as the estimated distance (kilobases, $\mathrm{Kb}$ ) between consecutive ones; $\mathbf{B}$ - Silverstained polyacrylamide gels, in which PCR amplification products $(8 \mu \mathrm{L})$ have been electrophoresed, show the migration of DNA bands. Approximate molecular sizes are 91, 130, 189, 121, 124, 118 and 133 basepairs (bp), respectively for D16S283, STR7, D16S291, KG8, D16S3395, STR3 and D16S521. Two bands observed within the expected size are indicated by arrowheads for every locus, each corresponding to the amplification of a distinct allele. Slower-moving bands may correspond to heteroduplexes formed by hybridization between strands from different allele amplifications or unspecific products. Arrows indicate a very faint band in the tumor sample as compared to the leukocyte DNA amplification in both D16S291 and KG8 loci. Two results are presented for the KG8 locus, each one from a different sample preparation of DNA from the AML-containing paraffin block. 
to $16 \mathrm{p} 13.3 .^{3}$ Therefore, we searched for loss of heterozygosity at $16 \mathrm{p} 13.3$, comparing patient DNA from leukocytes and AML tissue. We analyzed 11 microsatellites, with primers available at http:// www.ncbi.nih.gov/unists. After paraffin removal from tissue sample, DNA was purified (QIAGEN, Germantown, MD), and polymerase chain reaction (PCR) was performed, disclosing seven informative microsatellites (heterozygous in patient blood sample). Loss of heterozygosity was detected at KG8 microsatellite marker, for which the leukocyte DNA revealed heterozygosity, and the tumor sample had convincing amplification of a single allele, whereas for the other one very low intensity PCR amplification was observed (Figure 8, arrow). PCR testing of a DNA sample prepared from novel AML paraffin sections disclosed KG8 heterozygosity even for the tumor sample. One possible explanation is the presence of more endothelial and fibroblast cells in the latter sample, which are part of the tumor but should not have the mutation. Nevertheless, we also observed loss of heterozygosity at the D16S291 marker, for which the lower allele band was missing when compared to the leukocyte amplification product (Figure 8, arrow).

Further immunohistochemistry analyses have been carried out to address the expression of the TSC proteins, hamartin (TSC1) and tuberin (TSC2), with the following antibodies: rabbit polyclonal anti-hamartin (HF6, a kind gift of Vijaya Ramesh, Massachusetts General Hospital, Boston, $M A)^{4}$ and rabbit polyclonal anti-tuberin (TSC2, IA22, Sigma, St Louis, MI). We detected reasonable levels of hamartin (TSC1) and relatively low levels of tuberin (TSC2) in the AML, when compared to the negative control where the primary antibody has been omitted (Figure 9). On the other hand, staining under the same conditions was observed similarly for both hamartin and tuberin in the normal kidney tissue (Figure 10), supporting the observation of relatively low expression of the TSC2 gene in the AML.

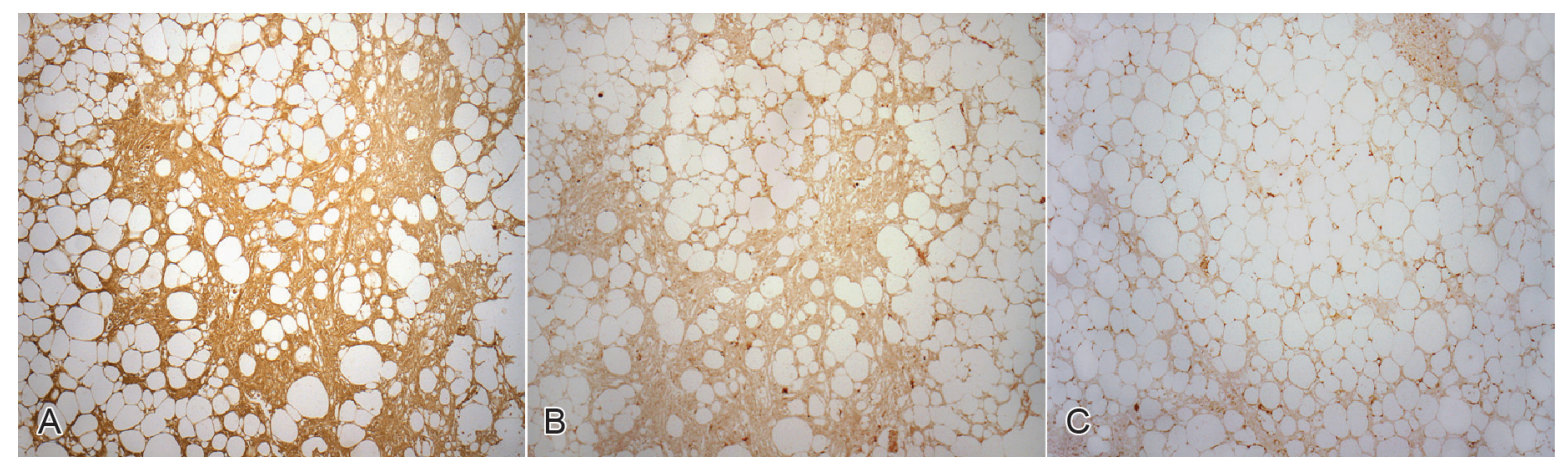

Figure 9 - Photomicrography of the tumoral mass. Renal AML shows positive immunoreactivity for hamartin (TSC1) in (A) and light staining for tuberin (TSC2) in (B) when compared to the negative control (C, antirabbit antibody). $200 X$ magnification.



Figure 10 - Photomicrography of the kidney. Kidney sections have been submitted to immunohistochemistry under the same conditions as in Figure 9. Renal tissue shows relatively similarly strong immunoreactivity for hamartin (TSC1, A) and tuberin (TSC2, B), when compared to the negative control (C, anti-rabbit antibody). $200 \times$ magnification. 


\section{DISCUSSION}

Renal AMLs are benign mesenchymal neoplasm, named so by Morgan et al. ${ }^{5}$ because of the complex tissue composition represented by a variable proportion of mature adipose tissue, smooth muscle cells, and dysmorphic blood vessels. However, Grawitz, in 1900, had already used this denomination to describe a large renal tumor comprised of fat, muscle, and blood vessels. ${ }^{6-8}$ AMLs are derived from a unique cell that has been designated as perivascular epithelioid cell. The classical perivascular epithelioid cell is typically clustered around blood vessels and may be scattered haphazardly within an AML., ${ }^{9,10}$ These cells show positive immunoreactivity for HMB-45 and other melanocytic markers. Other studies showed that tumor cells of pulmonary lymphangiomyomatosis also express HMB-45, as well as sugar tumor of the lung, creating the concept of a family of tumors called PEComas. ${ }^{11}$ The World Health Organization recognized the PEComa family as a group of mesenchymal tumors composed of these distinctive perivascular epithelioid cells. ${ }^{12}$

By definition, $A M L$ is considered to be benign even in the event of vascular or regional lymph node involvement, which is regarded as indicative of multifocal growth rather than an aggressive behavior. ${ }^{13,14}$ They may involve surrounding tissues like perinephric fat, renal sinus, renal vein, lymph nodes, and adrenal glands; invade the inferior vena cava and the right atrium, posing a frequent challenge to be differentiated from renal cell carcinoma. ${ }^{6,15}$ Classical AMLs present abundant fat tissue and therefore are somewhat easily diagnosed by CT or magnetic resonance imaging (MRI). However, many of them are not suspected because of the lack of fat tissue evidence, being called poor-fat AMLs, which do not differ in prognosis from the classical ones.

AMLs may also be classified as monophasic when they are composed predominantly or exclusively of one component, or triphasic when the three components (smooth muscle, fat and dysmorphic blood vessels) are present. The AMLs were recently classified as regular or clinically benign AMLs (when no epithelioid component is present) and epithelioid angiomyolipoma (EAML) (formerly called atypical AML), which are composed partially or entirely of atypical large epithelioid cells with abundant cytoplasm, vesicular nuclei, and prominent nucleoli. ${ }^{16}$ This denomination requires the presence of a minimum of $5 \%$ of the epithelioid component. ${ }^{15}$ Approximately one-third of the EAML have been reported to present metastasis or local recurrences. ${ }^{16,17}$ Epithelioid cellular morphology also can be seen in regular benign AMLs. Consequently, the term "epithelioid" as it applies to AMLs should be restricted to a morphologic description of cells with an epithelioid pattern as opposed to a spindle cell pattern, regardless of whether or not there is cytological atypia. Therefore, Brimo et al. ${ }^{16}$ denote AMLs with epithelioid morphology as "epithelioid AMLs" that are then divided into epithelioid AMLs with and without atypia - the former category associated, in the literature, with malignant potential. ${ }^{16}$

Although angiomyolipoma may rise in different sites of the body; namely, hard palate, adrenal gland, mediastinum, pancreas, and pelvis, they are mostly observed in the kidney and liver. ${ }^{17-22}$ Renal AML has an incidence varying between $0.02 \%$ and $0.3 \%$ (in patients without tuberous sclerosis complex [TSC]). They are described in two types: isolated angiomyolipoma and angiomyolipoma associated with TSC. $6,7,15,23$ The former represents almost $80 \%$ of cases, which typically develop in middle-aged women, and the latter represents the remaining $20 \%$ associated to TSC, known as Bourneville disease. ${ }^{6,24}$ Despite the fact that there is no significant difference in the frequency of AML detected in asymptomatic males or females, in patients treated surgically for AML, females outnumber males by a ratio of $4.8: 1$ in those with TSC, and 4.5:1 in those without TSC..$^{25,26}$ The consistent increased frequency in females may be due, in part, to hormonal differences as AMLs express progesterone and estrogen receptors, and perhaps explains the rapid growth and higher propensity to hemorrhage during pregnancy. ${ }^{6,27}$

While most cases of AML are found incidentally during imaging examinations and are asymptomatic, others may reach huge proportions presenting life-threatening symptoms or encroaching insidiously on the normal renal parenchyma leading to renal failure..$^{28,29}$ When symptomatic ( $40 \%$ of the cases), AML can present as a palpable mass, flank pain, or hematuria. Usually tumors do not uniformly become symptomatic until they reach the size of $4 \mathrm{~cm}$; after that, symptoms will be present in 68$80 \%$ of patients. ${ }^{30}$ Ruptures and renal hemorrhage have been reported to occur with lesions $>4 \mathrm{~cm} .^{7,15}$ Dysmorphic blood vessels within AML may appear thick, but they lack normal elastin; they are tortuous and do not show normal tapering. ${ }^{6}$ Aneurysms frequently develop as the AML enlarges, which can rupture causing retroperitoneal hemorrhage accompanied by sudden flank or back pain and signs of shock-the dreadful morbidity associated with AML, called Wunderlich syndrome. ${ }^{31}$ This complication occurs in $50-60 \%$ of the cases, ${ }^{6}$ and in up to $20 \%$ imposes nephrectomy. ${ }^{23}$ 
Pulmonary lymphangioleiomyomatosis (LAM) is a rare benign disease characterized by cystic changes in the pulmonary parenchyma and smooth muscle proliferation, leading to a mixed picture of interstitial and obstructive disease. Complications of this entity may comprise pneumothorax, chylothorax, and hemoptysis. Similarly to AML, LAM exhibits estrogen receptors reacting to hormonal influence. Anti-estrogen drugs (like tamoxifen) have proved to be beneficial in slowing the disease process. ${ }^{7}$

AML and LAM constitute major features of TSC diagnosis. The association between AML and TSC accounts for $20 \%$. In these cases, AMLs are typically large lesions and bilateral; on the other hand, $80 \%$ of patients with TSC present AML.

LAM is also a major feature for clinical diagnosis of TSC and can be detected in 26-39\% of these patients. The concomitance of LAM and AML in patients with TSC diagnosis is $60 \% .15,32,33$ Regarding the revised criteria for the clinical diagnosis of $\mathrm{TSC}^{34}$ the presence of two major features are sufficient for definite clinical diagnosis, but when AML and LAM are simultaneously present, another feature of TSC is required for a definite diagnosis. ${ }^{35}$ In the case reported here, the patient did not present skin or nail abnormalities; the brain CT and Doppler echocardiogram were normal. Fundoscopic examination was normal. Based on as much clinical and laboratory data as we were able to get, the diagnosis of TSC could not be achieved.

Imaging diagnosis of AML include ultrasound, color flow Doppler, CT, MRI. The classical ultrasound appearance of an AML is the hyper-reflective lesion with acoustic shadowing. AML has been described as the most hyper-reflective renal lesion, due to a combination of its fat content, the blood vessels within the tumor, and its heterogeneous nature. ${ }^{36,37}$ The subset of an AML with a minimal fat component, which represents a minority, will present as isoreflective to renal parenchyma. The demonstration of fat on CT is highly suggestive of AML, although not pathognomonic, but remains the major discriminative sign between $A M L$ and renal cell carcinoma (RCC). In an acute setting, CT is the most useful imaging examination, assessing hemorrhage and establishing an underlying diagnosis. ${ }^{38}$ Diagnosis of AML by MRI also depends on the detection of fat within the lesion, which is assessed by the difference between fat-suppressed and non-fat-suppressed sequences. ${ }^{30}$

In case of equivocal imaging results, a biopsy may be used to discriminate from other renal lesions. The immunohistochemistry of the spindled and epithelioid smooth muscle cells of AML are positive for vimentin, muscle-specific actin, smooth muscle actin, desmin, and CD 117 (c-KIT). ${ }^{10,39}$ The development of human melanoma black-45 (HMB45 ) and other melanocytic markers such as Melan $A$, has increased the reliability of the biopsies, as virtually all AMLs stain positive for these antibodies. Epithelial markers such as cytokeratin, frequently seen in RCC, are absent in AML, and HBM-45 is negative in RCC. ${ }^{40}$

Treatment of AML depends on the tumor size, the presence of symptoms, and, more recently, on the size of aneurysms detected by angiography. Symptomatic patients with lesions $\geq 4 \mathrm{~cm}$ or aneurysm $>5 \mathrm{~mm}$ should be treated with selective transcatheter renal artery embolization, enucleation, or partial nephrectomy. Patients asymptomatic should be monitored every 6 months. ${ }^{41,42}$ The 2012 International Tuberous Sclerosis Complex Consensus Conference recently reviewed the guidelines for management of TSC patients, and recommend that asymptomatic, growing AMLs larger than $3 \mathrm{~cm}$ should have mTOR inhibitors as first-line therapy. ${ }^{43}$ The optimal treatment of $A M L$ is logically focused on sparing renal tissue ${ }^{23}$, but in case of huge tumors and hemorrhage accompanied by hemodynamic instability or shock, nephrectomy is unavoidable.

We observed loss of heterozygosity in two loci linked to TSC2 gene, KG8 and D16S291. Although a second sample was not able to confirm KG8 results, we should take into consideration that the tumor has not been microdissected and it is composed of different cell types involved in blood vessel and interstitium formation that should lack the mutation. KG8 and D16S291 are adjacent markers in our study. PKD1 gene lies between them, in a 200-Kb DNA segment. No intragenic microsatellite is available for the TSC2 gene. KG8 lies in its very 3 '-end (see Figure 8). Therefore, the two losses of heterozygosity observed in this study are indicative of a single mutational event in the tissue that originated the tumor, probably a deletion of one copy of TSC2. The extension of this TSC2 somatic gene deletion could not be ascertained, though it should include its 3'-end and extends downstream for at least $200 \mathrm{~Kb}$. Moreover, our results suggest that the other somatic mutational hit, which is necessary to the oncogenic cascade, is unlikely to be a large deletion within the region where the microsatellites are located. It could be either, an intragenic deletion, a point mutation or an inactivating posttranslational modification of the TSC2 protein. ${ }^{44}$ Due to the paucity of polymorphic microsatellite markers within the TSC2 gene and the low quality of DNA obtained from the paraffin-embedded sample, we 
could not search for the second mutation. On the other hand, we performed immunohistochemistry analyses that indicated relatively low levels of TSC2 expression when compared to the negative control, corroborating that the patient has inactivating mutations in the TSC2 gene. In agreement, staining for the TSC1 protein (hamartin) disclosed relatively higher expression levels in the AML, and expression similar to tuberin (TSC2) in the kidney tissue.

\section{REFERENCES}

1. Carsillo T, Astrinidis A, Henske EP. Mutations in the tuberous sclerosis complex gene TSC2 are a cause of sporadic pulmonary lymphangioleiomyomatosis. Proc Natl Acad Sci USA. 2000;97:6085-90. http://dx.doi.org/10.1073/ pnas.97.11.6085

2. Crooks DM, Pacheco-Rodriguez G, DeCastro RM, et al. Molecular and genetic analysis of disseminated neoplastic cells in lymphangioleiomyomatosis. Proc Natl Acad Sci USA. 2004;101:17462-7. PMid:15583138 PMCid:PMC536045. http://dx.doi.org/10.1073/pnas.0407971101

3. Qin W, Bajaj V, Malinowska I, Lu X, et al. Angiomyolipoma have common mutations in TSC2 but no other common genetic events. PLoS One. 2011;6:e24919. PMid:21949787 PMCid:PMC3174984. http://dx.doi.org/10.1371/journal. pone.0024919

4. Murthy V, Haddad LA, Smith N, Pinney D, Tyszkowski $\mathrm{R}$, Brown D, Ramesh V. Similarities and differences in the subcellular localization of hamartin and tuberin in the kidney. Am J Physiol Renal Physiol. 2000;278:F737-46. PMid:10807585.

5. Morgan GS, Straumfjord JV, Hall EL. Angiomyolipoma of the kidney. J Urol. 1951;65:525-7. PMid:14825528.

6. Wahab S, Rizwan AK, Thapa M, Wahab A, Ahmad I. Giant Angiomyolipoma associated with a dilated vessel prone to hemorrhage. Iran J Kidney Dis. 2009;3:168-71. PMid:19617667.

7. Nasir Kiran, Ahmad A. Giant renal angiomyolipoma and pulmonary lymphangiomyomatosis. Saudi J Kidney Dis Transpl. 2010;21:314-9.

8. Grawitz P. Demonstration eines grossen Angio-Myo-Lipoms der Niere. Deutsch Med Wochenschr. 1900;26:290.

9. Weeks DA, Malott RL, Arnesen M, et al. Hepatic angiomyolipoma with striated granules and positivity with melanoma-specific antibody (HMB-45): a report of two cases. Ultrastruct Pathol. 1991;15:563-71. http://dx.doi. org/10.3109/01913129109016264

10. Ashfaq R, Weinberg AG, Albores-Saavedra J. Renal angiomyolipomas and $\mathrm{HMB}-45$ reactivity. Cancer. 1993;71:3091-7. http://dx.doi.org/10.1002/10970142 (19930515) $71: 10 \% 3$ C 3091 : : A I D CNCR2820711032\%3E3.0.CO;2-5
11. Bonetti F, Pea M, Martignoni G, et al. Clear cell ('sugar') tumor of the lung is a lesion strictly related to angiomyolipoma - the concept of a family of lesions characterized by the presence of the perivascular epithelioid cells (PEC). Pathology. 1994;26:230-6.

12. Folpe AL. Neoplasms with perivascular epithelioid cell differentiation (PEComas). In: Fletcher CDM, Unni KK, Mertens F, editors. Pathology and genetics of tumors of soft tissue and bone. Lyon: IARC Press; 2002. (IARC WHO Classification of Tumours Series).

13. Davis CJ, Woodward PJ, Dehner LP, et al. Pathology and genetics of tumours of the urinary system and male genital organs. Lyon: IARC Press; 2004.

14. Murphy WM, Grignon DJ, Perlman EJ. Tumors of the kidney, bladder, and related urinary structures. Washington: American Registry of Pathology; 2004.

15. Lane BR, Aydin H, Danforth T, et al. Clinical correlates of renal angiomyolipoma subtypes in 209 patients: Classic, fat poor, tuberous sclerosis associated and epithelioid. J Urol. 2008;180:836-43. PMid:18635231. http://dx.doi. org/10.1016/j.juro.2008.05.041

16. Brimo F, Robinson B, Guo C, Zhou M, Latour M, Epstein JI. Renal epithelioid angiomyolipoma with atypia: A series of 40 cases with emphasis on clinicopathologic prognostic indicators of malignancy. Am J Surg Pathol. 2010;34:71522. PMid:20410812.

17. Yang L, Feng XL, Shen S, et al. Clinicopathological analysis of 156 patients with angiomyolipoma originating from different organs. Oncol Lett. 2012;3:586-90. http://dx.doi.org/10.3892/ ol.2012.554

18. Alvarez AC, Fernández SJ, Fernández CM, et al. Sporadic oral angiomyolipoma. Case report. Med Oral Patol Oral Cir Bucal. 2007;12:E391-3.

19. Elsayes KM, Narra VR, Lewis JS Jr, et al. Magnetic resonance imaging of adrenal angiomyolipoma. J Comput Assist Tomogr. 2005;29:80-2. http://dx.doi.org/10.1097/01. ret.0000152863.97865.47

20. Amir AM, Zeebregts CJ, Mulder HJ. Anterior mediastinal presentation of a giant angiomyolipoma. Ann Thorac Surg. 2004;78:2161-3. http://dx.doi.org/10.1097/01. rct.0000152863.97865.47

21. Heywood G, Smyrk TC, Donohue JH. Primary angiomyolipoma of the pancreas. Pancreas. 2004;28:443-5. http://dx.doi. org/10.1097/00006676-200405000-00014

22. Gronchi A, Diment J, Colecchia M, et al. Atypical pleomorphic epithelioid angiomyolipoma localized to the pelvis: a case report and review of the literature. Histopathology. 2004;44:292-5. http://dx.doi.org/10.1111/j.03090167.2004.01801.x

23. Bisslerr JJ, Kingswood JC. Renal amgiomyolipoma. Kidney Int. 2004;66:924-34. PMid:15327383. http://dx.doi.org/10.1111/ j.1523-1755.2004.00838.x 
24. Hajdu SI, Foote FW Jr. Angiomyolipoma of the kidney: report of 27 cases and review of the literature. J Urol. 1969;102:396-401. PMid:5343474.

25. Fujii Y, Ajima J, Oka K, et al. Benign renal tumors detected among healthy adults by abdominal ultrasonography. Eur Urol. 1995;27:127.

26. Eble JN. Angiomyolipoma of kidney. Semin Diagn Pathol. 1998;15:21-40. PMid:9503504.

27. Henske EP, Ao X, Short MP, et al. Frequent progesterone receptor immunoreactivity in tuberous sclerosis-associated renal angiomyolipomas. Mod Path.1998;11:665-8.

28. Schillinger F, Montagnac R. Chronic renal failure and its treatment in tuberous sclerosis. Nephrol Dial Transplant. 1996;11:481-5. http://dx.doi.org/10.1093/oxfordjournals. ndt.a027315

29. Clarke A, Hancoc E, Kingswood C, et al. End-stage renal failure in adults with the tuberous sclerosis complex. Nephrol Dial Transplant. 1999,14:988-91. http://dx.doi.org/10.1093/ ndt/14.4.988

30. Halpenny D, Snow G, McNeil G, Torreggiani WC. The radiological diagnosis and treatment of renal angiomyolipoma - current status. Clin Radiol. 2010;65:99108. http://dx.doi.org/10.1016/j.crad.2009.09.014

31. Chesa Ponce N, Artiles Hernandez JL, Ponce socorro $\mathrm{JM}$, et al. Wunderlich's syndrome as the first manifestation of a renal angiomyolipoma. Arch Esp Urol. 1995;48:305-8.

32. Franz DN, Brody A, Meyer C, et al. Mutational and radiographic analysis of pulmonary disease consistent with lymphangioleiomyomatosis and micro nodular pneumocyte hyperplasia in women with tuberous sclerosis. Am J Resp Care Med. 2001;164:661-8. http://dx.doi.org/10.1164/ ajrccm.164.4.2011025

33. Costello LC, Hartman TE, Ryu JH, et al. High frequency of pulmonary lymphangioleiomiomatosis in women with tuberous sclerosis complex. Mayo Clin Proc. 2000;75:591-4. http://dx.doi.org/10.4065/75.6.591

34. Northrup H, Krueger DA; International Tuberous Sclerosis Complex Consensus Group. Tuberous Sclerosis Complex Diagnostic Criteria Update: Recommendations of the 2012 International Tuberous Sclerosis Complex Consensus
Conference. Pediatr Neurol. 2013;49:243-54. http://dx.doi. org/10.1016/j.pediatrneurol.2013.08.001

35. Northrup H, Koenig MK, Au KS. Tuberous Sclerosis Complex. In: Pagon RA, Bird TD, Dolan CR, Stephens K, Adam MP, editors. Gene Reviews ${ }^{\mathrm{TM}}$ [Internet]. Seattle: University of Washington; 1993 - [updated 2011 Nov 23].

36. Charboneau JW, Hattery RR, Ernst EC 3rd, et al. Spectrum of sonographic findings in 125 renal masses other than benign simple cyst. AJR Am J Roentgenol. 1983;140:87-94. http://dx.doi.org/10.2214/ajr.140.1.87

37. Hartman DS, Goldman SM, Friedman AC, et al. Angiomyolipoma: ultrasonic-pathologic correlation. Radiology. 1981;139:451-8.

38. Sherman JL, Hartman DS, Friedman AC, et al. Angiomyolipoma: computed tomography-pathologic correlation of 17 cases. AJR Am J Roentgenol. 1981;137:1221-6. http:// dx.doi.org/10.2214/ajr.137.6.1221

39. Makhlouf HR, Remotti HE, Ishak KG. Expression of KIT (CD117) in angiomyolipoma. Am J Surg Pathol. 2002;26:4937. http://dx.doi.org/10.1097/00000478-200204000-00012

40. Lienert AR, Nicol D. Renal angiomyolipoma. BJU International. 2012;11 Suppl 4:25-7. http://dx.doi.org/10.1111/j.1464410X.2012.11618.x

41. Oesterling JE, Fishman EK, Goldman SM, et al. The management of renal angiomyolipoma. J Urol. 1986;135:11214.

42. Yamakado K, Tanaka N, Nakagawa T, et al. Renal angiomyolipoma: relationships between tumor size, aneurysm formation, and rupture. Radiology. 2002;225:78-82. http:// dx.doi.org/10.1148/radiol.2251011477

43. Krueger DA, Northrup H; International Tuberous Sclerosis Complex Consensus Group. Tuberous Sclerosis Complex Surveillance and Management: Recommendations of the 2012 International Tuberous Sclerosis Complex Consensus Conference. Pediatr Neurol 2013;49:255-265. http://dx.doi. org/10.1016/j.pediatrneurol.2013.08.002

44. Han S, Santos TM, Puga A, et al. Phosphorylation of tuberin as a novel mechanism for somatic inactivation of the tuberous sclerosis complex proteins in brain lesions. Cancer Res. 2004;64(3):812-6. http://dx.doi.org/10.1158/0008-5472. CAN-03-3277

\section{Conflict of interest: None}

Submitted on: $21^{\text {th }}$ May 2013

Accept on: $28^{\text {th }}$ November 2013

Correspondence: Divisão de Clínica Médica Hospital Universitário da Universidade de São Paulo

Av. Prof. Lineu Prestes, 2565 - Cidade Universitária - São Paulo/SP - Brazil

CEP: 05508-000 - Phone: +55 (11) 3091-9200

E-mail: fpfcampos@gmail.com 